ISSN: 2224-0616

Int. J . Agril. Res. Innov. Tech. 8 (2): 61-69, December 2018

DOI: https://doi.org/ 10.3329/ijarit.v8i2.40557

Available online at https://ijarit.webs.com

https:// www.banglajol.info/index.php/ IJ ARIT

\title{
LONG RUN RELATIONSHIP BETWEEN ECONOMIC GROWTH, EXPORT, POPULATION AND INVESTMENT OF ETHIOPIA
}

\section{Leta1* and L. Zemedkun²}

\begin{abstract}
The objective of this study is to examine the long-run relationship between economic growth, population, export, and investment in Ethiopia using annual data collected from the World development indicator, and FAOSTAT for 18 years from 1990-2007 E.C. Co integration and Granger Causality test. Stationary properties of the data and the order of integration of the data were tested using the Augmented Dickey-Fuller (ADF) test. Variables were non-stationary at levels but stationary in first differences. The long-run effects of Population, export and investment on Economic growth indicated that these variables are positively related to economic growth and statistically significant at $1 \%$ level.
\end{abstract}

Keywords: Economic, growth, Annual GDP, Population, Investment

${ }^{1} \mathrm{PhD}$ Fellow, Department of Agricultural Economics, College of Agriculture and Environmental Science, Haramaya University, Ethiopia

${ }^{2}$ Assistant Professor, Department of Agricultural Economics, College of Agriculture and Environmental Science, Haramaya University, Ethiopia.

*Corresponding author's email: leta4mijena@gmail.com (M. Leta)

Cite this article as: Leta, M. and Zemedkun, L. (2018). Long run relationship between economic growth, export, population and investment of Ethiopia. Int. J. Agril. Res. Innov. Tech. 18(2), 61-69.

\section{Introduction}

For the past two decades, numerous empirical studies have been undertaken to determine what are the main factors that drive economic growth. There are two groups of researchers with respect to the main factors that drive economic growth. One includes those investigating the correlation between export and economic growth and the hypothesis that export expansion is attributed to a country's economic performance (Feder, 1983; Ram, 1987). The other includes those attempting to determine the relationship between economic growth and investment in the hypothesis that economic growth may be driven by investment through export growth or vice versa (Baldwin and Seghezza, 1996; Rodrik, 1995). Which factor, export or investment, is more responsible for economic growth has remained an issue of debate.

\section{Statement of the Problem}

According to Global Multidimensional Index (GMI), published by Oxford University (2015), Ethiopia ranks the third poorest country in the world, just ahead of Niger followed by South Sudan. The majority of the Ethiopian population is poor subsistence farmers who grow crops and rear animals just to feed themselves and their families. The large majority of destitute people, about 52 million are living in Ethiopia.
In a similar argument, many scholars argue that FDI has an adverse effect on development. They complaining that increased FDI does not always contribute to upgrading but sometimes may even act to reduce the host country's long run potential, leading to a crowding-out effect whereby domestic firms are displaced or outcompeted by foreign-owned MNEs, hence affecting economic development negatively (Tang and Selvanathan, 2008).

During the last five years, the exports of Ethiopia have increased at an annual rate of $24.6 \%$, from $\$ 1.85$ billion in 2009 to $\$ 5.56$ Billion in 2014 . Ethiopian export is dominated by few raw or semi processed agricultural products which have been the main contributors to the country's foreign exchange earnings. Coffee, which is very critical to the Ethiopian economy (with exports around $\$ 400$ million dollars a year) very often, meets low prices on the international market, which puts the entire Ethiopian economy in a very bad situation (Espen, 2006). The export sector is the primary sector for enhancing the foreign exchange earnings; there are various bottlenecks that prevent the sector from playing its role in the development of the national economy.

The Ethiopian economic growth registered over the last few years is not a deniable fact for it has 
got recognition both from the World Bank and the International Monetary Fund. However, the major issue that deserves a great concern is, more likely, how to keep the growth sustainable. Thus, this study was aimed to examine the long run relationship of Economic Growth and other macroeconomic variables like population, export, import and investment in Ethiopia.

\section{Objectives}

General objective

The major objective of this study is to examine the long-run relationship between economic growth, population, Export, and investment in Ethiopia.

\section{Specific objectives}

Specific objectives include:

i. To identify if there exists causal relationships and its direction among Economic grouth and population, export and investment in Ethiopia.

ii. To examine whether there exists long run equilibrium among economic growth, population, export and investment in Ethiopia.

iii. To assess how Population, export and investment contribute to economic growth to adjust to its short run and long run equilibrium due to shocks inevitable in the economy.

\section{Methodology}

\section{Data Source}

Secondary data type was used for this particular study. Time series data on GDP growth as it is a $\log \mathrm{GDP}_{\mathrm{t}}=\beta_{0}+\beta_{1} \log \mathrm{Pop}_{\mathrm{t}}+\beta_{2} \log \operatorname{Inv}_{\mathrm{t}}+\beta_{3} \log \operatorname{Exp}_{\mathrm{t}}+\varepsilon_{\mathrm{t}}$

where,

$\mathbf{G D P}=$ Gross Domestic Product; Pop $=$ Total population; Exp $=$ Exports;

Inv = Investment; $\boldsymbol{\varepsilon}=$ error term; $\mathrm{t}=$ time series period;

$\boldsymbol{\beta}_{\mathbf{0}}=$ the intercept; $\boldsymbol{\beta}_{1}, \boldsymbol{\beta}_{2}, \boldsymbol{\beta}_{\mathbf{3}}, \boldsymbol{\beta}_{\mathbf{4}}$ are coefficient for the explanatory variables.

Estimation Techniques

The estimation technique employed in this study is co-integration and error-correction modeling technique. To estimate the co-integration and error-correction, three steps are required: these are testing for order of integration, the cointegration test and the error correction estimation.

\section{Unit root test}

Testing of the stationarity of the time series ensures that the variables used in the analysis are not subjected to spurious correlation and should be done before the estimation of the econometric model. There are at least two important reasons why unit root test is so necessary. One is to know if shocks have permanent or transitory effects. proxy measure for economic growth, Population, gross investment, export and import from 1990 2007 were obtained from World Development indicators and Food and Agriculture Organization (FAOSTAT) accessed from their online data base.

\section{Descriptiveanalysis}

Among the descriptive statistics, graphical and tabular illustration are the once employed as they are widely applied by many other researchers.

\section{Econometric model and specification}

To establish the causality relationship between the four variables, the VAR model in the form: $(\mathrm{VAR})=(\mathrm{GDP}$, Pop, Exp, Inv) was used. The dependent variable is Economic Growth (GDP, \$ billion). The explanatory variables are Population (million), Export (\$million), and investment (\$ billion). These variables were chosen because of their theoretical and empirical justification on economic growth of a given country. However, before the estimation of the specified long run and the short-run growth models, the time series properties of the variables of interest were first explored to eliminate any trend element that could lead to spurious parameter estimates GDP as theoretically outlined was used as proxy for Economic growth. Based on the underlined assumption, the model for GDP could be written as:

$\mathrm{GDP}=\mathrm{fs}$ ( Pop, Inv, Exp, Inv)

In order to evaluate the impact of the dependant variables, the model is modified by transforming the equation into a log form;

i. 


$$
\begin{aligned}
& \Delta \mathrm{y}_{\mathrm{t}}=\alpha_{\mathrm{o}}+\alpha_{1 \mathrm{yt}-1}+\sum_{i=1}^{n} \alpha \Delta \mathrm{yt}+\mathrm{e} \quad \text { (model with intercept only) } \\
& \text { ii. } \quad \Delta \mathrm{y}_{\mathrm{t}}=\alpha_{\mathrm{o}}+\alpha_{1 \mathrm{t}}+\alpha_{2} \mathrm{y}_{\mathrm{t}-1}+\sum_{i=1}^{n} \alpha \Delta \mathrm{yt}+\mathrm{e}_{\mathrm{t}} \quad \text { (model with trend and intercept ) ....... (4) } \\
& \text { iii. } \quad \Delta \mathrm{y}_{\mathrm{t}}=\alpha_{1} \mathrm{y}_{\mathrm{t}-1}+\sum_{i=1}^{n} \alpha \Delta \mathrm{yt}+\mathrm{e}_{\mathrm{t}}(\text { model does not have trend and intercept ) ...... (5) }
\end{aligned}
$$

Where:

' $\mathbf{y}$ ' a vector for all-time series variables under consideration in a particular regression model (our variables of interest); ' $\mathbf{t}$ ' is a linear time trend, ' $\boldsymbol{\Delta}$ ' is the first difference operator, ' $\mathbf{a}_{\mathbf{0}}$ ' is a constant, ' $\mathbf{n}$ ' is the optimum number of lags in the dependent variable determined by maximum lag selection criteria (Akaike Information Criteria (AIC) and ' $\mathbf{e}$ ' is the random error term; and the Phillip-Perron (PP) is equation is represented as:

$$
\Delta y_{t}=\alpha_{0}+\alpha y_{t-1}+e_{t}
$$

Hypothesis:

Null Hypothesis, Ho: Variable is not stationary or has unit root.

Alternative Hypothesis, HA: Variable is stationary or does not have unit root.

\section{Co-integration test}

The basic idea behind co-integration is that if, in the long-run, two or more series variables move closely together, even though the series themselves are trended, the difference between them is constant. The most commonly used methods for co integration test are the EngleGranger two step test (Engle and Granger, 1987) and the Johansen Maximum Likelihood procedure (J ohansen and J uselius, 1990).

For this analysis, J ohansen (1988) co-integration procedure was employed because this approach is performing better than other co-integration tests. J ohansen co- integration test will be employed if variables are non stationary at levels but they become stationary when differenced. J ohansen's methodology takes its starting point in the vector auto regression (VAR) of order $\mathrm{P}$ given by: In conducting the Johansen co-integration test, we estimate the following model:

$$
y_{t}=\mu+\Delta_{1} y_{t-1}+\ldots \ldots+\Delta \rho y_{t-\rho}+\varepsilon_{t}
$$

Where:

$\mathbf{Y}_{\mathbf{t}}^{\prime}$ is an 'nx1' vector of variables that are integrated of order commonly denoted (1) and ' $\varepsilon_{t}$ is an 'nx1' vector of innovations. VAR can be rewritten as

$$
\Delta \mathrm{y}_{\mathrm{t}}=\mu+\eta \mathrm{y}_{\mathrm{t}-1}+\ldots \ldots+\sum_{\mathrm{i}=1}^{\mu-1} \tau_{\mathrm{t}} \Delta \mathrm{y}_{\mathrm{t}-1}+\varepsilon_{\mathrm{t}} \ldots \ldots \ldots \text { (8) }
$$

Two set of statistics purposed by Johansen and J uselius (1990) which indicate the number of cointegrating rank, trace statistic, $L R\left(\lambda_{\text {trace }}\right)$ and maximum likelihood statistics.

The null hypothesis for the eigen value test is $r=$ equals the number of co-integration vectors in the model, while the null hypothesis for trace test is $r$ $\leq$ the number of co-integration vectors in the model. The test statistics of the null hypothesis for $\lambda_{\max }$ is " $r$ " of no co-integrating vectors against alternative hypothesis that " $\mathbf{r + 1}$ " co-integrating vector. Where, " $T$ " is the number of observations, and the " $\lambda_{\mathbf{i}}$ "is the estimated eigen value from the matrix.

\section{Error correction model (ECM)}

If co-integration is proven to exist, then the third step requires the construction of error correction mechanism to model dynamic relationship. The purpose of the error correction model is to indicate the speed of adjustment from the shortrun equilibrium to the long-run equilibrium state. The greater the co-efficient of the parameter, the higher the speed of adjustment of the model from the short-run to the long run.

If the variables are found to be integrated, a vector error correction model (VECM) would be estimated. Because a co-integrating relationship deals only with long run relationship without considering the short run dynamics. Thus, if the series LnGDP, LnPop, LnExp and LnInvt are found to be I(1) and co-integrated, the ECM model is represented by the following equation:

$$
\text { for trace statistics, } \operatorname{LR}\left(\lambda_{\text {trace) (r) }}\right)=-\mathrm{T} \sum_{\mathrm{i}=\mathrm{r}+1}^{\mathrm{k}} \ln \left(1-\lambda_{\mathrm{t}}\right) \text {. }
$$




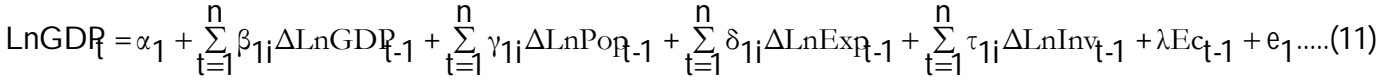

$$
\begin{aligned}
& \operatorname{LnPop}=\alpha_{2}+\sum_{\mathrm{t}=1}^{\mathrm{n}} \beta_{2 \mathrm{i}} \operatorname{LnGDP}_{\mathrm{t}-1}+\sum_{\mathrm{t}=1}^{\mathrm{n}} \gamma_{2 \mathrm{i}} \operatorname{LnPop}_{-1}+\sum_{\mathrm{t}=1}^{\mathrm{n}} \delta_{2 \mathrm{i}} \Delta \operatorname{LnExp}+\sum_{\mathrm{t}=1}^{\mathrm{n}} \tau_{2 \mathrm{i}} \operatorname{LnIny}_{\mathrm{i}-1}+\lambda \mathrm{Ec}_{\mathrm{t}-1}+\mathrm{e}_{1} \ldots \ldots \ldots \ldots . . .(2) \\
& \operatorname{LnExp}=\alpha_{3}+\sum_{\mathrm{t}=1}^{\mathrm{n}} \beta_{3 \mathrm{i}} \Delta \operatorname{LnGDP}_{\mathrm{t}-1}+\sum_{\mathrm{t}=1}^{\mathrm{n}} \gamma_{3 \mathrm{i}} \Delta \operatorname{LnPop}_{-1}+\sum_{\mathrm{t}=1}^{\mathrm{n}} \delta_{3 \mathrm{i}} \Delta \operatorname{LnExp}_{-1}+\sum_{\mathrm{t}=1}^{\mathrm{n}} \tau_{3 \mathrm{i}} \operatorname{LnInY}_{-1}+\lambda \mathrm{Ec}_{\mathrm{t}-1}+\mathrm{e}_{1} \ldots \ldots \ldots . .1(3) \\
& \operatorname{LnIny}=\alpha_{4}+\sum_{\mathrm{t}=1}^{\mathrm{n}} \beta_{4 \mathrm{i}} \Delta \operatorname{LnGDP}_{\mathrm{t}-1}+\sum_{\mathrm{t}=1}^{\mathrm{n}} \gamma_{4 \mathrm{i}} \Delta \operatorname{LnPop}_{-1}+\sum_{\mathrm{t}=1}^{\mathrm{n}} \delta_{4 \mathrm{i}} \Delta \operatorname{LnExp}_{-1}+\sum_{\mathrm{t}=1}^{\mathrm{n}} \tau_{4 \mathrm{i}} \operatorname{LnInY}_{-1}+\lambda \mathrm{Ec}_{\mathrm{t}-1}+\mathrm{e} .
\end{aligned}
$$

Where:

Where LnGDP, LnPop, LnExp, LnInv are logarithm transformation of Economic growth (GDP in Billions, \$US), Population (in millions), export (in millions, \$US), and investment (in Billion, \$US) respectively; $\mathbf{E C}_{\mathbf{t - 1}}$ is the error correction term is the lagged estimated error series. " $\boldsymbol{\Delta}$ " is the difference operator and $\varepsilon_{\mathrm{t}}$ is the error term which takes care of other variables that could have influence on Economic growth but not specified in the model and while $\mathrm{n}$ is the optimal lag length orders of the variables.

Granger-Causality/Block Exogeneity Test

Existence of co-integration implies that there is a long-run equilibrium relationship existing between the variables in the equation. When the existence of the long run relationship among the variables is established, then further analysis such the Granger causality can be applied. Granger causality distinguishes between unidirectional and bi-directional causality (Granger and Newbold, 1988).

a). Unidirectional Granger-causality from $X$ to $Y$ and not Vice-versa

b). Unidirectional Granger-causality from $Y$ to $X$ and not Vice-versa

c). Bidirectional (or feedback) causality from $\mathrm{X}$ to $\mathrm{Y}$, and from $\mathrm{Y}$ to $\mathrm{X}$.

c). Lack of Causality: There is no relationship among the variables,

In order to test for Granger causality, we will estimate a VAR model as follows:

$\left[\log \mathrm{y}_{\mathrm{t}}\right]=\alpha_{\mathrm{o}}+\beta_{1}\left[\log \mathrm{y}_{\mathrm{t}-1}\right]+\beta_{2}\left[\log \mathrm{y}_{\mathrm{t}-2}\right] \ldots+\beta_{\mathrm{n}}\left[\log \mathrm{y}_{\mathrm{t}-\mathrm{n}}\right]+\mu_{\mathrm{t}}$

$\mathrm{Y}=\left[\begin{array}{llll}\text { GDP } & \text { POP } & \text { Ex } & \text { Inv }\end{array}\right]$

where ' $\mathbf{t}$ ' is the time subscript, ' $\mathbf{n}$ ' is the number of lags for the 'VAR, $\boldsymbol{\alpha}$ ' is the vector of constant and $\boldsymbol{\beta}_{1}, \boldsymbol{\beta}_{2}, \ldots, \boldsymbol{\beta}_{3}$ are all parameter matrices and the variables have their usual meaning.

Accordingly, the direction of causality between Economic growth (LnGDP), Total population (LnPop), Export (LnExp), Import and Gross Investment (LnInv) would be examined. The test for five variables can be formulated as follows:

\section{Variables Definition and J ustification}

Economic Growth (GDP): There are many ways of measuring economic growth of a given country. These include real output per capita and growth in real gross domestic product. This study however used GDP as a measure of economic growth. This is because other researchers have used it in their work as dependent variable (Frimpong and Oteng-Abayie, 2008).

- GDP (Gross Domestic Product, measured in \$ billion) is the sum of gross value added by all resident producers in the economy plus any product taxes and minus any subsidies not included in the value of the products. It is calculated without making deductions for depreciation of fabricated assets or for depletion and degradation of natural resources. Data are in current U.S. dollars. Figures for GDP are converted from domestic currencies using single year official exchange rates.

- Pop (Total population) measured in millions: is based on the definition of population, which counts all residents regardless of legal status or citizenship.

- Exp (Exports, measured in \$ million): goods and services represent the value of all goods and other market services provided to the rest of the world. They include the value of merchandise, freight, insurance, transport, travel, royalties, license fees, and other services, such as communication, construction, financial, information, business, personal, and government services.

- Inv (Investment, measured in \$ billion) : investment means creation of capital

- goods capable of producing other goods or services.

\section{Results and Discussion}

\section{Descriptive analysis}

Annual data of GDP (mill. \$US, total Population (mill), Export (mill \$US), and investment (mill 
\$US) of Ethiopia from the year 1990 to 2007 E.C. were statistically summarized and presented in Table 1. The result shows that the mean value of the GDP, Pop and Expand Inv are 21252.18, 76.415, 1002.67, and 15587.61, respectively. The ranges of standard deviation of these series are
15633.92, 10.60, 880.71 and 11369.26 for GDP, Pop, Exp, and Inv; the maximum value also 55612.23, 94.56, 3307.25, and 33217.5, for GDP, Pop, Exp, and Inv. Graphical representations of these series are presented in Figure 1 below.

Table 1. Summary statistics result of LnGDP, LnPop, LnExp, and LnInv.

\begin{tabular}{|llllll|}
\hline Variable & Obs & Mean & Std. Dev. & Min & Max \\
\hline GDP & 18 & 21252.18 & 15633.92 & 7700.83 & 55612.23 \\
\hline Pop & 18 & 76.415 & 10.60 & 62.71 & 94.56 \\
\hline Exp & 18 & 1002.67 & 880.71 & 43.62 & 3307.25 \\
\hline Inv & 18 & 15587.61 & 11369.26 & 3158.01 & 33217.5 \\
\hline
\end{tabular}

Source: Own computation.

From Figure 1, One can observe that Inv and GDP showed an irregular pattern over the time span of 1990 to 2007 E.C. GDP was increasing and above 30 bill\$ from 1990 to 1992. But from 19921993, it was dramatically decreased and become below 10 bill\$. However, it has shows steadily increased thereafter. On the other hand, Investment although showing a slightly increasing until 1994 EC, but thereafter increased considerably until 2011 EC. Export shows insignificant increase throughout the time this paper considered. However, it a remarkable increase could be observed from 2000 to 2005 EC.

\section{Test for unit root}

A stationary series is denoted as $\mathrm{I}(0)$, meaning integrated of order zero (Dickey and Fuller, 1979). The data were transformed into natural logarithms to account for the expected nonlinearity's in the relationships and also to achieve stationarity in variance (Chang and Caudill, 2005). All the variables used in this study were first tested for long run relationship between economic growth, population, export, and investment.

$$
\Delta y_{t}=\alpha_{0}+\alpha y_{t-1}+e_{t}
$$

where $\alpha=\rho-1 ; u: s^{2} \operatorname{IID}\left(0, \delta^{2}\right)$

\section{Hypothesis:}

HO: $\rho=1\left(\mathbf{y}_{\mathbf{t}}\right.$ series has unit root or not Stationary or it)

HA: $\rho<\mathbf{1}\left(\mathbf{y}_{\mathbf{t}}\right.$ series is stationary or integrated of order zero)

The result of stationarity test indicated the rejection of the null hypothesis of no stationarity at $1 \%, 5 \%$ and also $10 \%$ significance level for trend and also without trend of all the series variables examined. Thus the variables examined were found to be non stationary at levels, but after taking first difference, we can reject null hypothesis which indicates that all of these variables are stationary at $1 \%$ and also at $5 \%$ significance level.

Table 2. Augmented Dickey Fuller (ADF) unit root test results at level.

\begin{tabular}{|lccccc|}
\hline Coefficient & Level I (0) t- & \multicolumn{3}{c|}{ Level of significance } & Decision \\
\hline$-0.14949(0.201)$ & statistics & $1 \%$ & $5 \%$ & $10 \%$ & \\
\hline$-0.32261(0.101)$ & 2.58 & -2.602 & -1.753 & -1.341 & Accept Ho \\
\hline$-0.390395(0.078)$ & -1.754 & -2.602 & -1.753 & -1.341 & Accept Ho \\
\hline$-0.275186(0.149)$ & -1.894 & -2.602 & -1.753 & -1.341 & Accept Ho \\
\hline
\end{tabular}

Source: Own computations

Table 3. Augmented Dickey Fuller (ADF) unit root test result at first difference.

\begin{tabular}{|llcccc|c|}
\hline Var. & Coefficient & Level I (1) & \multicolumn{3}{c|}{ Level of significance } & Decision \\
\hline LnGDP & $-0.6319^{* *}(0.029)$ & -2.43 & -2.624 & -1.761 & -1.345 & Reject Ho \\
\hline LnPop & $-1.0653^{* *}(0.011)$ & -3.994 & -2.624 & -1.761 & -1.345 & Reject Ho \\
\hline LnExp & $-1.256^{* * *}(0.000)$ & -4.861 & -2.624 & -1.761 & -1.345 & Reject Ho \\
\hline LnInv & $-0.9891^{* * *}(0.002)$ & -3.70 & -2.624 & -1.761 & -1.345 & Reject Ho \\
\hline
\end{tabular}

Source: Own computations

Note: ***; ** indicates stationary at I(1) at 1\% and 5\% level of significanœe, respectively. 
Selecting of number of lags

To test for co-integration, we must specify how many lags to include. Nielsen (2001) has indicated methods used to determine the lag order for a VAR model with I(1) variables. The order of the corresponding VECM is always one less than the VAR.

Table 4. Selection-order criteria result.

\begin{tabular}{|ccccccc|}
\hline Maximum rank & LL & eigen value & SBIC & HQIC & AIC \\
\hline 0 & -281.95164 & 33.83742 & 33.66086 & 33.64137 & - \\
\hline 1 & -267.97843 & 0.80678 & $33.36013^{*}$ & 32.87458 & 32.82099 \\
\hline 2 & -261.43289 & 0.53702 & 33.42336 & $32.71711^{*}$ & 32.63916 \\
\hline 3 & -258.48456 & 0.29310 & 33.57648 & 32.73781 & 32.64524 \\
\hline 4 & -256.92108 & 0.16801 & 33.5592 & 32.67639 & 32.57895 \\
\hline
\end{tabular}

Source: Own computations

As indicated by the table above, the Schwarz Bayesian information criterion (SBIC) method of optimum lag selection determine one lags for the data used in the model while, Hannan-Quinn information criterion (HQIC) method indicated two lags. Thus one lag was used to proceed for co-integration test.

\section{Co-integration Test}

This analysis adopted Johansen Maximum Likelihood procedure because it allows for all feasible co-integration relationship and the number of co-integrating vectors to be verified practically. The result of the co-integration condition (that is the existence of a long term linear relation) is presented in Table 5 and 6 below using methodology proposed by J ohansen and Juselius (1990). The trace statistic test (50.0611) is greater than $5 \%$ critical value implying that the hypothesis of no co-integrating equations (a maximum rank of zero) is rejected. However, we fail to reject the null hypothesis of at most one co-integrating equation.

Table 5. Unrestricted co-integration rank test (Trace) result.

Trend: constant

Sample: 1991 - 2007
Number of obs $=17$

$$
\text { Lags }=1
$$

\begin{tabular}{|cccccc|}
\hline Maximum rank & LL & eigen value & $\begin{array}{c}\text { trace } \\
\text { statistic }\end{array}$ & $\begin{array}{c}5 \% \text { critical } \\
\text { value }\end{array}$ & $\begin{array}{c}1 \% \text { critical } \\
\text { value }\end{array}$ \\
\hline 0 & & & $50.0611 * 1$ & 47.21 & 54.46 \\
\hline 1 & -281.952 & & $22.1147 * 5$ & 29.68 & 35.65 \\
\hline 2 & -267.979 & 0.80678 & 9.0236 & 15.41 & 20.04 \\
\hline 3 & -261.433 & 0.53702 & 3.1270 & 3.76 & 6.65 \\
\hline 4 & -258.485 & 0.29310 & & & \\
\hline
\end{tabular}

Source: Own computations for data obtained from FOSTA, World development indicator

Note: * indicates at least one cointegrating vectors at $5 \%$ level of significance respectively for the number of lags.

\section{Estimates of long run and error}

Correction model

The long-run effects of population, export and investment on economic growth indicated that these variables are positively related to economic growth and statistically significant at $1 \%$ level. This means that a one percent increase in population, export and investment will increase $28 \%, 238 \%$ and $774 \%$ in economic growth respectively, as these variables are theoretically acknowledged to enhance the capacity of the economy through the multiplier effect. The results revealed that the coefficient of the error correction term (ECT-1) which measures the adjustment towards long-run equilibrium was negative as expected -0.033, -0.0675, -0.594, and -0.052 for $\Delta$ LnGDP, $\Delta$ LnPop, $\Delta$ LnExp and $\Delta$ LnInv, respectively. 
Table 6. Vector error correction estimates result of economic growth of Ethiopia.

\begin{tabular}{|c|c|c|c|c|}
\hline ongru & & & & \\
\hline LnGDP & & & 1 & \\
\hline LnPop & & & $\begin{array}{l}0.29188 \text { *** } \\
(4.426211)\end{array}$ & \\
\hline LnExp & & & $\begin{array}{l}2.38061^{* * * *} \\
(0.0489924)\end{array}$ & \\
\hline LnInv & & & $\begin{array}{c}7.7402 * * * \\
(1.93348)\end{array}$ & \\
\hline constant & & & $\begin{array}{c}-2025.49^{* *} \\
(3.05664)\end{array}$ & \\
\hline Shortrun Estimat & & & & \\
\hline Error correction & $\Delta($ LnGDP (1) & $\Delta(\operatorname{LnPop}(1)$ & $\Delta(\operatorname{Ln} \operatorname{Exp}(1)$ & $\Delta(\operatorname{LnInv}(1)$ \\
\hline $\mathrm{EC}_{\mathrm{t}-1}$ & $\begin{array}{l}-0.032431 \text { ** } \\
(0.00995)\end{array}$ & $\begin{array}{l}-0.067464 \text { ** } \\
(0.01435)\end{array}$ & $\begin{array}{l}-0.59391 \text { *** } \\
(1.35797)\end{array}$ & $\begin{array}{l}-0.051573 \text { *** } \\
(0.01823)\end{array}$ \\
\hline$\Delta$ (LnGDP (1) & $\begin{array}{l}0.002431 \\
(0.009944)\end{array}$ & $\begin{array}{l}0.0707232 \\
(0.2892889)\end{array}$ & $\begin{array}{l}-0.0009253 \\
(0.0037847)\end{array}$ & $\begin{array}{l}0.0261097 \\
(0.1068003)\end{array}$ \\
\hline$\Delta($ LnPop (1) & $\begin{array}{l}0.067464 \text { *** } \\
(0.0143518)\end{array}$ & $\begin{array}{l}1.962654 \text { *** } \\
(0.4175213)\end{array}$ & $\begin{array}{l}-0.025677^{* * * *} \\
(0.0054623)\end{array}$ & $\begin{array}{l}0.7245767 \text { *** } \\
(0.1541414)\end{array}$ \\
\hline$\Delta(\operatorname{LnExp}(1)$ & $\begin{array}{l}6.593909 \text { *** } \\
(1.357966)\end{array}$ & $\begin{array}{l}191.8292 \\
(39.50578)\end{array}$ & $\begin{array}{l}-2.509662 \text { *** } \\
(0.5168459)\end{array}$ & $\begin{array}{l}70.81992 \text { *** } \\
(14.58483)\end{array}$ \\
\hline$\Delta(\operatorname{LnInv}(1)$ & $\begin{array}{l}-0.0515726 \text { ** } \\
(0.0182292)\end{array}$ & $\begin{array}{l}-1.500344^{* *} \\
(0.5303219)\end{array}$ & $\begin{array}{l}0.0196287 * * \\
(0.0069381)\end{array}$ & $\begin{array}{l}-0.5539001^{* *} \\
(0.1957854)\end{array}$ \\
\hline
\end{tabular}

Source: Own computations using stata software.

Note: $* * *, * *$ and $*$ indicate significance at the $1 \%$, 5\%and $10 \%$ levels, respectively.

\section{Granger-Causality Test}

The estimation result indicated that there exists bidirectional causality significant at $1 \%$ between export and population. The implication of the result is that an increase in production of high quality of goods and services through hiring more skilled labour with high payment will increases export, which in turn leads to cause to produce more skilled and highly productivity labour. The result also shows that there is a unidirectional causality relation from export to economic growth (GDP), from investment to export significant at $1 \%$. Investment in new technology and capital can increase the productive capacity of the economy.

Table 7. Granger causality Wald tests result.

\begin{tabular}{|ccccc|}
\hline Equation & Excluded & Chi $^{2}$ & df & Prob $>$ Chi $^{2}$ \\
\hline GDP & Inv & 2.3769 & 1 & 0.013 \\
\hline GDP & Pop & 4.0001 & 1 & 0.045 \\
\hline GDP & Exp & 3.4513 & 1 & 0.003 \\
\hline GDP & All & 4.0145 & 3 & 0.003 \\
\hline Inv & GDP & 0.84563 & 1 & 0.028 \\
\hline Inv & Pop & 5.3611 & 1 & 0.051 \\
\hline Inv & Exp & 6.1329 & 1 & 0.015 \\
\hline Inv & All & 14.182 & 3 & 0.003 \\
\hline Pop & GDP & 0.70853 & 1 & 0.400 \\
\hline Pop & Inv & 6.402 & 1 & 0.011 \\
\hline Pop & Exp & 21.388 & 1 & 0.000 \\
\hline Pop & All & 26.563 & 3 & 0.000 \\
\hline Exp & GDP & 1.5793 & 1 & 0.029 \\
\hline Exp & Inv & 9.0317 & 1 & 0.003 \\
\hline Exp & Pop & 23.686 & 1 & 0.000 \\
\hline Exp & All & 26.038 & 3 & 0.000 \\
\hline
\end{tabular}

Source: Own computations using stata software. 


\section{Diagnostic tests}

Diagnostics test are usually undertaken to detect model misspecification and as a guide for model

Normality tests

The Jarque-Bera normality test is used to determine whether the regression errors are normally distributed. The standard test for the normality of a data series in Stata is a joint asymptotic test whose statistic is calculated from improvement. These tests include serial correlation, normality and heteroscedasticity tests.

the skewness and kurtosis of the residuals as follows (www.cambridge.org/ Stata Guide Cambridge University Press, n.d). Jarque-Bera normality test result showed that the probability value is greater than the $\chi^{2}$ value that we accept the null-hypothesis of residuals are normally distributed.

Table 8. J arque-Bera Normality Tests result.

\begin{tabular}{|cccc|}
\hline \hline Equation & $\chi^{2}$ & df & Prob $>\chi^{2}$ \\
\hline dgp & 7.851 & 2 & 0.11973 \\
\hline inv & 9.517 & 2 & 0.50858 \\
\hline pop & 0.938 & 2 & 0.62578 \\
\hline exp & 0.680 & 2 & 0.71171 \\
\hline ALL & 18.986 & 8 & 0.11493 \\
\hline
\end{tabular}

Null Hypothesis: Residuals are multivariate normal Source: Own computations using stata software

\section{Serial correlation test}

The serial correlation test can be done using the Durbin-Watson test or the lagrange multiplier (LM) test. It helps to identify the relationship that may exist between the current value of the regression residuals and lagged values. This review analysis used the LM test to investigate serial correlation.

The Hypotheses for the Durbin Watson test are: $\mathrm{H}_{0}=$ no serial correlation.

$\mathrm{H}_{1}=$ serial correlation exists .

\section{Conclusion and Recommendations}

\section{Conclusion}

The objective of this study is to examine the longrun relationship between economic growth, population, export, and investment in Ethiopia using annual data collected from the World development indicator, and FAOSTAT of 18 years from 1990-2007 E.C. Econometric methodology like Co-integration and Granger Causality test was also employed. At first, the stationary properties of the data to verify the existence of spurious relation among the series data and, order of integration were tested using the Augmented Dickey-Fuller (ADF) test. We used the VAR and VECM approach to determine the long-run and short-run relationship between these variables.

Furthermore, the granger causality test was employed to find the direction of causality. The test result indicated that there exists bidirectional causality statistically significant at less than $1 \%$ between export and population. There is also statistically significant at less $5 \%$ a bidirectional causal relation between investment and population and economic growth (GDP). Similarly, the test result also reveals that there is a unidirectional causality relation from two variables. Normality Tests was conducted using J arque-Bera to determine whether the regression errors are normally distributed.

Another diagnostics test includes the test of serial correlation. This test was adopted using the Durbin-Watson test or the lagrange multiplier (LM) test. It helps to identify the relationship that may exist between the current value of the regression residuals and lagged values. The analysis used the LM test to investigate serial correlation. Statistical analysis found that (Prob> chi2) was 0.693 which justify the rejection of alternative hypothesis of existence serial correlation, and acceptance of the nullhypothesis of the LM test that the residuals are not serially correlated is accepted at $5 \%$ level of significance.

\section{Recommendations}

Based on the finding of this particular study of Economic growth of Ethiopia, for which data obtained from World Bank development indicator and FAOSTAT baseline, the following policy recommendations are forwarded.

- Population has positive impact on Ethiopian economic growth. In order to achieve an observable contribution of population to economic growth, the increase in population has to be integrated with the human capital formation through education and skill development. So that the government of Ethiopia has to give due attention to the adequate quality of education that can bring transformation in technology and innovation 
as a spring board of economic growth through population growth.

- Exports of goods and service have significant positive impact on Ethiopian economic growth as it can be evidenced theoretically. Therefore, the Ethiopian Government should strengthen the existing strategy of export diversification and production of quality goods that enables the country competitive at international market and harvests enough foreign exchange currency.

- Investment affects the economic growth of Ethiopia positively. The Ethiopian Government should design and establish conducive investment policy both for domestic and foreign investors in areas where it can benefit the country. Domestic investment has to be encouraged through domestic saving for it is groundwork for investment. Thus, the government of Ethiopia has to strengthen the existing saving strategies like selling of government Bonds, expanding financial institutions, banking system of payment for employs, etc.

\section{References}

Baldwin, R. and Seghezza, E. 1996. Testing tradeinduced investment-ld growth. National Bureau of Economic Research (NBER). Working paper No. 5416. 123p.

Chang, T. and Caudill, S.B. 2005. Financial development and economic growth: The case of Taiwan. Appl. Econ. 37: 1329-1335. https:// doi.org/ 10.1080/000368404200033870 $\underline{2}$ developments in a concept of causality. J . Econometrics. 39: 199 - 211.

Dickey, D. and Fuller, W.A. 1979. Estimators for autoregressive time series with a unit root. J. American Stat. Assoc. 74(366): 427-431. https:// doi.org/ 10.2307/2286348.

Dickey, D. and Fuller, W.A. 1981. Likelihood ratio statistics for autoregressive time series with a unit root. Econometrica. 49(4): 1057-1072.

Engle F. and Granger, J . 1987. Co-Integration and Error correction: Representation, Estimation and Testing. J. Econometrica. 55(2): 251-276.

Espen, V. 2006. Economic Prospects for Ethiopia and Challenges for Poverty Reduction Bergen, Norway. pp. 203-205
Feder, G. 1983. On exports and economic growth. J. Dev. Econ. 12: 59 - 73.

Frimpong, J.M. and Oteng-Abayie, E.F. 2008. Bivariate Causality Analysis between FDI Inflows and Economic Growth in Ghana. Int. Res. J. Finance Econ. 3(1): 63-67.

Granger, C. and Newbold, P. 1988. Some recent

Gujarati, D. 2004. Basic Econometrics. Fourth Edition. MoGraw-Hill Companies. pp. 225227.

Gujarati, D.N. 2003. Basic Econometrics. $4^{\text {th }}$ Edition. McGraw-Hill Companies, Inc, New York. pp. 163-165.

Johansen, S. 1988. Statistical analysis of cointegration vectors. J. Economic Dynamics and Control. 12: 231 - 254.

Johansen, S. and Juselius, K. 1990. Maximum likelihood estimation and inference on cointegration: with applications to the demand for money. Oxford Bull. Econ. Stat. 3(2): 127-130.

Nielsen, B. 2001. Order determination in general vector autoregressions. Working paper, Department of Economics, University of Oxford and Nuffield College.

Oxford University. 2015. Oxford Poverty \& Human Development Initiative OPHDI 2015. Global Multidimensional Poverty Index. $\quad$ https:// www.ophi.org.uk/wpcontent/ uploads/Global-MPI-8-pager_10_15.pdf Accessed on May 21, 2017.

Phillips, P.C.B. and Perron, P. 1988. Testing for a unit root in time series regression. Biometrika. $\quad 75(2)$ : $\quad 335-346$. https:// doi.org/ 10.1093/ biomet/ 75.2.335

Ram, R. 1987. Exports and economic growth: Some additional evidence. Econ. Dev. Cultural Change. 5(2): 117.

Rodrik, D. 1995. Getting Interventions Right: How South Korea and Taiwan Grew Rich. Economic Policy. No. 20. https:// doi.org/ 10.3386/w4964.

Tang, S. and Selvanathan, S. 2008. Foreign Direct Investment, Domestic Investment, and Economic Growth in China: A Time Series Analysis. Working paper No. 416. 448.

www.cambridge.org/ Stata Guide Cambridge University Press, accessed on J une 19/2016. 